\title{
EFFECTS OF SELECTED SOUTH AFRICAN PLANT EXTRACTS ON HAEMOLYSIS AND COAGULATION
}

Running Title: Plant extracts and blood parameters

\author{
Werner CORDIER ${ }^{1}$, Allan D CROMARTY ${ }^{1}$, Elsabie BOTHA ${ }^{2}$, Vanessa \\ STEENKAMP ${ }^{1^{*}}$ \\ ${ }^{1}$ Department of Pharmacology, Faculty of Health Sciences, University of Pretoria, Pretoria, South \\ Africa \\ ${ }^{2}$ Department of Haematology, National Health Laboratory Services (NHLS), Pretoria, South Africa
}

\begin{abstract}
The use of herbal preparations for staunching blood flow and reducing the risk of vascular thrombosis is common worldwide. In this study, aqueous and methanolic extracts of plants used to treat blood associated complaints were investigated to determine their effects on red blood cell haemolysis and coagulation. The extent of haemolysis was determined spectrophotometrically. Prothrombin time (PT) and activated partial thromboplastin time (aPTT) as indicators of coagulation rate were determined using a coagulatometer. All of the plant extracts tested had a significant effect on coagulation time, prolonging the aPTT. Cassia petersiana had the greatest prolonging effect on PT compared to the control, PBS. As all of the herbal extracts tested had a delaying effect on coagulation, patients using herbal/plant therapies should be cautioned to stop their medication before surgery.
\end{abstract}

\footnotetext{
* Corresponding author: Tel +27-12-3192547; fax: +27-12-3192411

Department of Pharmacology, University of Pretoria, P.O. Box 2034, 0001, Pretoria, South Africa E-mail: vanessa.steenkamp@up.ac.za
} 
KEYWORDS : Anticoagulant, coumarins, haemolysis, herbal, plant extracts, salicylic acid.

ABBREVIATIONS : aPTT - activated partial thromboplastin time; PBS - phosphate buffered saline; PPP - platelet poor plasma; PT - prothrombin time.

\section{INTRODUCTION}

Blood platelets play an exceptionally important role in the circulatory system during haemostatic events due to their ability to aggregate and initiate coagulation ${ }^{1}$. The end point of the coagulation cascade is the formation of a solid haemostatic plug or clot from fluid blood, which diminishes blood flow from the damaged vessel and maintains haemostasis ${ }^{1-3}$. The coagulation cascade is a complex system where inactive precursors of clotting factors are activated through proteolysis - a process in which each factor catalyses the formation of the next sequential factor. This cascade occurs via one of two pathways: (i) the tissue factor (extrinsic) or (ii) contact (intrinsic) pathway. Both pathways ultimately lead to the formation of a platelet clot, which is required for repair of vascular damage ${ }^{4}$. Dysfunction in platelet activity can have detrimental effects on the body ${ }^{1}$.

Increased coagulation is commonly associated with cardiovascular diseases such as coronary heart disease and hypertension ${ }^{2}$. Increased platelet activity causes coagulation in static blood, i.e. a vascular thrombosis can form without vascular damage $^{5}$. If this thrombus should dislodge from the vascular endothelium and create a blockage in circulation, it leads to a thromboembolism, which can cause ischaemic loci and subsequent damage to the affected area ${ }^{6}$. 
Decreased coagulation leads to a prolonged bleeding time when vascular damage occurs due to the inability to form functional and stable clots. Reasons for this include diseases such as haemophilia A or the use of drugs such as aspirin, heparin and warfarin ${ }^{7}$. It can lead to episodes of severe bleeding, even from small lacerations that can remain open for several days. Procoagulant treatment is generally given, where missing clotting factors or vitamin $\mathrm{K}$ is administered to improve the efficacy of the coagulation cascade ${ }^{1}$.

Various pharmaceutical compounds find their origins in plant material ${ }^{8}$. Salix alba L. (Salicaceae) is used ethnomedicinally as an anti-inflammatory agent. It's active phytochemical salicylic acid was later transformed into acetylsalicylic acid (aspirin) which acts as a potent antiplatelet $\mathrm{drug}^{7}$. Novel anticoagulants can thus be found in other plants. Jatropha curcas L., used as a haemostatic, is reported to have procoagulant abilities at high concentrations, but anticoagulant activity at low concentrations ${ }^{9}$. The Chinese formulation, 'Yunnan Baiyao' (which contains roots of Panax notoginseng (Burkill) C.Y.Wu \& K.M.Feng) was shown to reduce perioperative bleeding during cervical laminoplasty ${ }^{10}$. Antiplatelet and anticoagulant properties have been attributed to plants such as Achillea falcata L., Rhus verniciflua DC., Umbilicaria esculenta (Miyoshi) Minks, Curcuma longa L. and Artemisia dracunculus L. which are used ethnomedicinally in the treatment of haemorrhaging or as anticoagulants ${ }^{3,6,11-13}$.

Few studies have been carried out to determine the direct effect of plant extracts on blood parameters such as haemolysis and coagulation. It is important to be aware that the use of remedies can decrease the efficacy of the coagulation cascade thus resulting in serious complications during surgical procedures. Many South African plants are used ethnomedicinally for blood disorders or wound healing, 
making it imperative to determine the validity thereof (Table 1). As there is little data available on the latter, the aim of this study was to determine the haemolytic and anticoagulant properties of nine South African plant extracts used to treat bloodrelated disorders.

\section{METHODS AND MATERIALS}

\section{Plant material}

\subsection{Collection}

Plants were collected from the Limpopo Province and the identity of the specimens was verified by Mr. P. Tshisikawe (University of the North). Voucher specimens beginning with LT were accessioned to the Department of Toxicology (Onderstepoort Veterinary Institute, Pretoria) and specimens starting with $\mathrm{NH}$ to the Soutpansbergensis Herbarium (Louis Trichardt). Harpagophytum procumbens, Medicago sativa and Salix alba, were used to prepare control extracts and were bought from a health shop.

\subsection{Preparation of extracts}

Extraction was performed as described by Pallant and Steenkamp ${ }^{14}$. Plant material was air-dried and ground (YellowLine Grinder, Merck Chemicals Co.) to a fine powder. Aqueous and methanolic extracts were made by adding $10 \mathrm{~g}$ powdered plant material to $100 \mathrm{ml}$ relevant solvent. Extracts were sonicated in a water bath for $30 \mathrm{~min}$ after which they were incubated at $4^{\circ} \mathrm{C}$ for $24 \mathrm{~h}$. The extracts were centrifuged (10 $\mathrm{min}, 1000 \mathrm{~g})$ and the supernatant filtered (0.22 $\mu \mathrm{m}$ Millipore). Aqueous extracts were lyophilized and the methanolic extracts were evaporated to dryness in vacuo at $<40^{\circ} \mathrm{C}$. 
Gravimetric yields were performed to determine the percentage yield of the plant material. The extracts were made up to a concentration of $2 \mathrm{mg} / \mathrm{ml}$ in PBS and thereafter serially diluted (test range $1 \mathrm{mg} / \mathrm{ml}$ to $0.125 \mathrm{mg} / \mathrm{ml}$ ).

\section{Blood and blood parameters}

\subsection{Blood collection}

This study was approved by the Ethics Committee of the Faculty of Health Sciences at the University of Pretoria (ethics number 164).

Blood was collected from three healthy volunteers. For the haemolysis assay the blood was transferred to centrifugation tubes containing $3.8 \%$ acid-citratedextrose (1:9). For PT and aPTT, the blood was drawn directly into sodium citrate evacuated blood tubes (Vacutainer, BD).

For the haemolysis assay the centrifugation tubes were centrifuged for 10 min at $230 \mathrm{~g}$ and the erythrocyte layer diluted to $10 \%$ in PBS. For the PT and aPTT assays, platelet poor plasma (PPP) was obtained by centrifugation of sodium citrate tubes for $15 \mathrm{~min}$ at $1500 \mathrm{~g}$.

\subsection{Haemolysis measurements}

Salicylic acid (Sigma Chemical Co) was dissolved in methanol in a ratio of 1:5 and then serially diluted in PBS $(0.125,0.25,0.5$ and $1 \mathrm{mg} / \mathrm{ml})$.

Into $1,5 \mathrm{ml}$ tubes was placed: $250 \mu \mathrm{l}$ plant extract of varying concentrations and $250 \mu \mathrm{l}$ of a $10 \%$ erythrocyte suspension. Tubes were centrifuged for $10 \mathrm{~min}$ at $1000 \mathrm{~g}$ and $37^{\circ} \mathrm{C}$. An aliquot of $10 \mu \mathrm{l}$ of the supernatant was added to the wells of a 96-well plate containing $165 \mu$ PBS. Absorbance was determined 
spectrophotometrically (ELx800 UV plate-reader, Bio-Tek Instruments, Inc.) at 540 $\mathrm{nm}$. The extent of haemolysis was calculated using the equation:

$$
\text { Percentage haemolysis }=\frac{\mathrm{A} \text { (sample) }-\mathrm{A} \text { (PBS Control) }}{\mathrm{A} 100 \%}
$$

A $($ sample $)=$ absorbance of sample

$\mathrm{A}($ PBS Control $)=$ absorbance of PBS as negative control

$\mathrm{A} 100 \%=$ absorbance of the distilled water as positive control

\subsection{PT and aPTT tests}

Tests were carried out using a Dade Behring BCT coagulometer (Department of Haematology, NHLS). Into a BCT coagulation cup: $250 \mu$ l plant extract of varying concentrations and $250 \mu \mathrm{l}$ PPP was added. Samples were incubated for $5 \mathrm{~min}$ at $37^{\circ} \mathrm{C}$.

For the PT test, $100 \mu \mathrm{l}$ Thromborel ${ }^{\circledR} \mathrm{S}$ (Dade Behring) was added to $50 \mu \mathrm{l}$ PPP-extract mixture and clotting time measured using the coagulometer. For the aPTT test, $50 \mu$ l Pathromtin ${ }^{\circledR} \mathrm{SL}$ (Dade Behring) was added to $50 \mu$ PPP-extract mixture, incubated for $1 \mathrm{~min}$ after which $50 \mu \mathrm{l}$ of $0.025 \mathrm{~mol} / \mathrm{l}$ calcium chloride (Dade Behring) was added and clotting time measured using the coagulometer. Heparin and PBS served as control.

\section{Thin Layer Chromatography}

For the detection of coumarins in the plant extracts, a mobile phase of diethyl ether:toluene $(50: 50 \mathrm{v} / \mathrm{v})$ saturated with $10 \%$ acetic acid was used. The mobile phase was prepared by addition of $10 \%$ acetic acid to the diethyl ether:toluene, after which the excess acetic acid was siphoned off. The extracts $\left( \pm 2.5 \times 10^{-3} \mathrm{mg}\right)$ were spotted onto $10 \times 20 \mathrm{~cm} \mathrm{C}_{18}$ silica gel plates (Merck). Warfarin $(1 \mathrm{mg} / \mathrm{ml}$ ) was 
included as standard. Visualization was performed by spraying with $5 \%$ methanolic potassium hydroxide (5 $\mathrm{g}$ potassium hydroxide in $100 \mathrm{ml}$ methanol) followed by inspection under long wave (360nm) UV.

For the detection of salicylates a mobile phase of hexane:ethyl acetate:glacial acetic acid $(65: 35: 5 \mathrm{v} / \mathrm{v})$ was used. The extracts $\left( \pm 2.5 \times 10^{-3} \mathrm{mg}\right)$ were spotted onto $10 \times 20 \mathrm{~cm} \mathrm{C}_{18}$ silica gel plates. Salicylic acid $(1 \mathrm{mg} / \mathrm{ml})$ and acetylsalicylic acid (1 $\mathrm{mg} / \mathrm{ml}$ ) (Sigma Chemical Co.) were included as references. Visualization was by means of long wave (360nm) UV.

\section{Statistical analyses}

All experiments were carried out in triplicate. Data was reported as mean \pm standard deviation. Statistical analyses were performed on all samples by comparison to the PBS control using the Mann-Whitney U test (a significance of $p<$ 0.05 was used).

\section{RESULTS AND DISCUSSION}

Extracts of nine of the tested plants increased haemolysis significantly ( $p$-value $<0.05$ ) relative to the control (Table 2). Salicylic acid, the methanolic extract of $\mathrm{H}$. Procumbens, and the aqueous extracts of Kigelia africana and Solanum panduriforme E. Mey resulted in a significantly lower percentage haemolysis than the

control. S. alba and H. procumbens are two plants known to contain salicylic acid ${ }^{15}$. The greatest haemolytic effect was observed in extracts of Solanum aculeastrum Dun. In studies of livestock consuming M. sativa (Fabaceae) it was found that the interaction of the plant with rumen bacteria caused an increase in haemolysis due to the saponin content, which lowers the stability of cell membrane, resulting in lysis ${ }^{16}$. 
Individuals suffering from glucose-6-phosphate dehydrogenase deficiency are also at a higher risk of haemolysis when consuming beans from the Fabaceae family such as Vicia faba L. ${ }^{17}$. Both Dalbergia melanoxylon Guill. \& Perr. and Cassia petersiana Belle. belong to the Fabaceae family and significantly increased haemolysis.

The prothrombin time (PT) and activated partial thromboplastin time (aPTT) are indicators of coagulation and are used to determine the clotting of the tissue factor and contact pathway respectively ${ }^{18}$. Standard clotting times for these two pathways are between 12.5 and $13.7 \mathrm{~s}$ for PT and between 31 and $39 \mathrm{~s}$ for $\mathrm{APTT}^{19}$. The methanolic extract of C. petersiana (Fabaceae) at concentrations of $0.25,0.5$ and 1 $\mathrm{mg} / \mathrm{ml}$ showed a significant increase in PT (17 s, $50 \mathrm{~s}$ and no clot, respectively), when compared to the control (13 s) (Figure 1). PT was also increased significantly by D. melanoxylon $(0.25 \mathrm{mg} / \mathrm{ml} ; 18.5 \mathrm{~s})$ and salicylic acid $(0.5$ and $1 \mathrm{mg} / \mathrm{ml} ; 17.3$ and 20 s, respectively)

Compounds known to suppress the extent of coagulation are the coumarins ${ }^{20}$. M. sativa is known to have an inhibitory effect on coagulation, which is expected as it does contain coumarins ${ }^{15}$. Warfarin is a coumarin that has the ability to inhibit vitamin K-dependent clotting factors, such as clotting factors II, VII, IX and $X^{1}$. The prolonged PT of plasma treated with C. petersiana, D. melanoxylon and salicylic acid indicates an inhibition of the tissue factor pathway, which relies on the presence of factor VII, which in turn relies on activation by vitamin $\mathrm{K}$. Warfarin and other vitamin $\mathrm{K}$ antagonists are known to lead to a prolonged $\mathrm{PT}^{1,18}$. The family Fabaceae is known to contain coumarins, which correlates with the increased PT. However, coumarins were not detected within C. petersiana using TLC (possibly due to concentrations below the limit of detection) $)^{21}$. No significant increase in PT was noted for any of the other extracts tested. 
Dihydroisocoumarins have been isolated from the roots of $\mathrm{K}$. africana (Bignoniaceae family) and these compounds have been found to elicit similar effects to coumarins i.e. increase the $\mathrm{PT}^{22}$. In this study we could not detect any coumarins in K. africana, though it's prolonging of PT points to the possible presence of similar compounds in the fruit. Furthermore, the family Bignoniaceae contains lapachol, which is known to inhibit vitamin K-epoxide reductase, an enzyme involved in the coagulation pathway ${ }^{22,23}$. Only the methanolic extract of $M$. sativa was found to contain coumarins when compared to the warfarin control (Figure 2, Rf-value = 0.42), although it did not prolong the PT.

The methanolic extract of S. panduriforme was found to contain salicylates (Figure 3, Rf-values $=0.82$ ). Even though salicylic acid is reported to be present in S. alba and $\mathrm{H}$. procumbens ${ }^{15}$, we were not able to detect any salicylic acid in these plants possibly due to concentrations being below the limit of detection of the method used $\left(6.25 \times 10^{-2} \mathrm{mg} / \mathrm{ml}\right)$. During the haemolysis test it was found that a significant decrease in haemolysis was found for salicylic acid at or above a concentration of $0.5 \mathrm{mg} / \mathrm{ml}$. This decrease in haemolysis was also seen for S. panduriforme, S. alba, H. procumbens and K. africana (which did not present with salicylates).

All extracts showed a significant increase in aPTT (Table 3). An increase in aPTT is indicative that the inhibitory effect is via the contact coagulation pathway ${ }^{18}$. As the contact pathway is controlled through the activation of a series of proteolytic clotting factors, it could be deduced that these extracts had inhibitory effects on these factors ${ }^{1,18}$. 


\section{CONCLUSION}

All of the plants tested in this study had significant anticoagulant activity. This effect was primarily via the contact pathway of the coagulation cascade. It was however not possible to determine which compound/s in the extracts were responsible for the activity. The greatest anticoagulant activity was seen in C. petersiana, which significantly increased both the PT and aPTT.

Normally surgical procedures require that any anticoagulant therapy should be ceased prior to undergoing the surgery, as the prolonged clotting time increases the risk of bleeding episodes. It is apparent that many plants and herbal preparations have the ability to decrease the efficacy of the coagulation cascade in vitro, as was proven in this study. This is an indication that herbals may have a significant effect on blood parameters, though it is not conclusive as in vivo studies will be required to determine true physiological effect.

\section{ACKNOWLEDGMENTS}

The Clinical Research Unit is thanked for their assistance in blood collection. The Department of Haematology at the National Health Laboratory Services is thanked for their assistance in the PT and aPTT assays. Funding was received from the University of Pretoria, Department of Pharmacology. 


\section{REFERENCES}

1. Rang HP, Dale MM, Ritter JM, Flower RJ. Rang and Dale's Pharmacology $6^{\text {th }}$ edition. Churchill Livingstone (Elsevier); 2007; pp. 331 - 333, 338.

2. Mekhfi H, Haouari ME, Legssyer A, Bnouham M, Aziz M, Atmani F, Remmal A, Ziyyat A. Platelet anti-aggregant property of some Moroccan medicinal plants. J. Ethnopharmacol. 2004;94;317-322.

3. Shahriyary L, Yazdanparast R. Inhibition of blood platelet adhesion, aggregation and secretion by Artemisia dracunculus leaves extracts. J. Ethnopharmacol. $2007 ; 114 ; 194-198$.

4. Chistokhodova N, Nguyen C, Calvino T, Kachirskaia I, Cunningham G, Miles DH. Antithrombin activity of medicinal plants from central Florida. J. Ethnopharmacol $2002 ; 81 ; 277-280$.

5. Bruno O, Schenone S, Ranise A, Bondavalli F, Barocelli E, Ballabeni V, Chiavarini M, Bertoni S, Tognolini M, Impicciatore M. New polycyclic pyrimidine derivatives with antiplatelet in vitro activity: synthesis and pharmacological screening. Bioorg. Med. Chem. 2001;9;629-636.

6. Jeon WK, Lee JH, Kim HK, Lee AY, Lee SO, Kim YS, Ryu SY, Kim SY, Lee YJ, Ko BS. Anti-platelet effects of bioactive compounds isolated from the bark of Rhus verniciflua Stokes. J. Ethnopharmacol. 2006;106;62-69.

7. Vane JR, Botting, RM. The mechanism of action of Aspirin. Thromb. Res. $2003 ; 110 ; 255-258$.

8. Butler MS. The role of natural product chemistry in drug discovery. J. Nat. Prod. 2004;67:2141-2153. 
9. Osoniyi O, Onajobi F. Coagulant and anticoagulant activities in Jatropha curcas latex. J. Ethnopharmacol. 2003;89;101-105.

10. Pan SF, Sun Y, Li F, Li GH, Jin DD, Zhang ZM, Luo ZJ, Ye ZX, Hu JH, Qiu GX. Effects of Yunnan Baiyao on peri-operative bleeding of patients undergoing cervical open-door laminoplasty: a multi-center randomized double-blind placebocontrol trial. Chung-Hua i Hsueh Tsa Chih [Chin Med J] 2006;86;1888-1890.

11. Aburjai T, Hudaib M. Antiplatelet, antibacterial and antifungal activities of Achillea falcata extracts and evaluation of volatile oil composition. Pharmacol. Magazine $2006 ; 2 ; 191-198$.

12. Kim MS, Lee KA. Antithrombotic activity of methanolic extract of Umbilicaria esculenta. J. Ethnopharmacol. 2006;105;342-345.

13. Lee HS. Antiplatelet property of Curcuma longa L. rhizome-derived ar-turmerone. Bioresource Technology 2006;97;1372-1376.

14. Pallant CA, Steenkamp V. In-vitro bioactivity of Venda medicinal plants used in the treatment of respiratory conditions. Human \& Experimental Toxicology. 2008;27:859-866.

15. Golembiewski J. University of Michigan Health System - Herbal Medicines reported to have effects on coagulation. http://www.med.umich.edu/1libr/aha/umherb04.htm 2008.

16. Tava A, Forti D, Odoardi M. Alfalfa saponins: isolation, chemical characterisation and biological activity against insects. Proceedings of the $X$ International Conference EUCARPIA, Lodi, Italy; 1992; pp. 283.

17. Yahya HI, Al-Allawi NA. Acute haemolytic episodes \& fava bean consumption in G6PD deficient individuals. Indian J. Med. Res. 1993;98;290-292. 
18. Krapp K. Preoperative Care. In: Encyclopedia of Nursing \& Allied Health; 2002; http://www.enotes.com/nursing-encyclopedia/preoperative-care.

19. Lentner C. Geigy Scientific Tables Volume 3. Ciba-Geigy Limited, Basle, Switzerland; 1984; p. 234.

20. Pochet L, Frederick R, Masereel B. Coumarin and isocoumarin as serine protease inhibitors. Curr. Pharmaceut. Des. 2004;10;3781-3796.

21. Etkin NL. Plants and Indigenous Medicine and Diet: Biobehavioral Approaches. Redgrave Publishing Company, New York; 1986; pp 235 - 238.

22. Hutchings A, Scott AH, Lewis G, Cunningham A. Zulu Medicinal Plants - An Inventory. University of Natal Press, Kwazulu-Natal; 1996 pp. 285-286, 181-186.

23. Preusch PC, Smalley DM. Vitamin-K, 2,3-Epoxide and Quinone Reduction: Mechanism and Inhibition. Free Radic. Res. 1990;8;401-415.

24. van Wyk B-E., van Oudtshoorn B, Gericke N. Medicinal Plants of South Africa. Briza Publications, South Africa; 1997.

25. Arnold H-J, Gulumian M. Pharmacopoeia of traditional medicine in Venda. J. Ethnopharm 1984;12;35-74.

26. Mabago DEN. The ethnobotany of the Vhavenda. MSc thesis 1990, University of Pretoria, Pretoria, South Africa.

27. van Wyk P. Trees of the Kruger National Park. Purnell, Cape Town; 1972.

28. Stayt H. The Bavenda. Frank Cass \& Co. Ltd., London.; 1986. 


\section{TABLES AND FIGURES}

Table 1. Plants investigated in this study with purported effects on blood parameters

\begin{tabular}{|c|c|c|c|c|}
\hline Plant Species & Family & $\begin{array}{l}\text { Voucher } \\
\text { number }\end{array}$ & $\begin{array}{l}\text { Plant } \\
\text { Part }\end{array}$ & $\begin{array}{l}\text { Traditional Medicinal } \\
\text { Uses }\end{array}$ \\
\hline $\begin{array}{l}\text { Kigelia africana (Lam.) } \\
\text { Benth. }\end{array}$ & Bignoniaceae & LT0023 & Fruit & Ulcer dressing ${ }^{24}$ \\
\hline $\begin{array}{l}\text { Cassine transvaalensis } \\
\text { (Burtt Davy) Codd. }\end{array}$ & Celastraceae & LT0018 & Bark & Haemorrhoids $^{25}$ \\
\hline $\begin{array}{l}\text { Parinari curatellifolia } \\
\text { Planch. ex. Benth. }\end{array}$ & Chrysobalanaceae & LT0010 & Bark & Wounds ${ }^{26}$ \\
\hline $\begin{array}{l}\text { Dichrostachys cinerea } \\
\text { (L.) Wright \& Arn. }\end{array}$ & Fabaceae & NH1871 & Root & Wounds ${ }^{21}$ \\
\hline Cassia petersiana Belle. & Fabaceae & LT003 & Roots & Stomach/tooth ache ${ }^{2 b}$ \\
\hline $\begin{array}{l}\text { Mundelea sericea Willd. } \\
\text { A. Chev. }\end{array}$ & Fabaceae & LT0025 & Roots & $\begin{array}{l}\text { Purification after } \\
\text { abortion/miscarriage }^{28}\end{array}$ \\
\hline $\begin{array}{l}\text { Dalbergia melanoxylon } \\
\text { Guill. \& Perr. }\end{array}$ & Fabaceae & LT0020 & Bark & $\begin{array}{l}\text { Prevent excessive } \\
\text { wound bleeding }^{25}\end{array}$ \\
\hline Medicago sativa L. & Fabaceae & $\begin{array}{l}\text { Health } \\
\text { shop }\end{array}$ & Leaves & $\begin{array}{l}\text { Mitigate premenstrual } \\
\text { syndrome, purported } \\
\text { anticoagulant effect } \\
\text { Contains coumarins }^{15}\end{array}$ \\
\hline $\begin{array}{l}\text { Harpagophytum } \\
\text { procumbens DC. }\end{array}$ & Pedaliaceae & $\begin{array}{l}\text { Health } \\
\text { shop }\end{array}$ & Roots & $\begin{array}{l}\text { Rheumatism, arthritis, } \\
\text { health tonic }^{15}\end{array}$ \\
\hline Salix alba L. & Salicaceae & $\begin{array}{l}\text { Health } \\
\text { shop }\end{array}$ & Bark & $\begin{array}{l}\text { Fever and aches } \\
\text { Contains salicylic acid }\end{array}$ \\
\hline $\begin{array}{l}\text { Solanum aculeastrum } \\
\text { Dun. }\end{array}$ & Solanaceae & LT0017 & Fruit & Wounds ${ }^{2 b}$ \\
\hline Solanum panduriforme E. & Solanaceae & LT0028 & Fruit & Wounds ${ }^{26}$ \\
\hline
\end{tabular}


Table 2. Extracts that had a significant effect on haemolysis $(p<0.05)$

\begin{tabular}{|c|c|c|c|}
\hline Extract & Plant & Concentration $(\mathrm{mg} / \mathrm{ml})$ & Haemolysis (\%) \\
\hline Aqueous & C. petersiana & 0.5 & $13.88 \pm 0.21$ \\
\hline \multirow{4}{*}{ Methanolic } & \multirow{4}{*}{ C. petersiana } & 0.125 & $15.07 \pm 0.95$ \\
\hline & & 0.25 & $15.67 \pm 0.55$ \\
\hline & & 0.5 & $20.46 \pm 1.29$ \\
\hline & & 1 & $23.92 \pm 0.54$ \\
\hline \multirow{2}{*}{ Aqueous } & \multirow{2}{*}{ C. transvaalensis } & 0.5 & $13.99 \pm 0.95$ \\
\hline & & 1 & $14.59 \pm 0.21$ \\
\hline \multirow{4}{*}{ Methanolic } & \multirow{4}{*}{ C. transvaalensis } & 0.125 & $14.24 \pm 0.41$ \\
\hline & & 0.25 & $14.12 \pm 0.54$ \\
\hline & & 0.5 & $14.71 \pm 0.95$ \\
\hline & & 1 & $16.27 \pm 1.15$ \\
\hline \multirow{2}{*}{ Methanolic } & \multirow{2}{*}{ D. cinerea } & 0.25 & $14.60 \pm 1.03$ \\
\hline & & 1 & $14.47 \pm 041$ \\
\hline Aqueous & D. melanoxylon & 1 & $14.83 \pm 0.83$ \\
\hline \multirow[t]{2}{*}{ Methanolic } & \multirow[t]{2}{*}{ H. procumbens } & 0.5 & $11.48 \pm 0.62$ \\
\hline & & 1 & $11.72 \pm 0.21$ \\
\hline \multirow{2}{*}{ Aqueous } & \multirow{2}{*}{ K. africana } & 0.25 & $11.72 \pm 0.42$ \\
\hline & & 0.5 & $11.84 \pm 0.36$ \\
\hline \multirow{2}{*}{ Aqueous } & \multirow{2}{*}{ S. aculeastrum } & 0.5 & $126.60 \pm 12.35$ \\
\hline & & 1 & $124.80 \pm 50.3$ \\
\hline \multirow{3}{*}{ Methanolic } & \multirow{3}{*}{ S. aculeastrum } & 0.25 & $73.21 \pm 13.75$ \\
\hline & & 0.5 & $144.70 \pm 14.04$ \\
\hline & & 1 & $139.60 \pm 8.49$ \\
\hline Aqueous & S. alba & 0.5 & $15.55 \pm 0.75$ \\
\hline \multirow{2}{*}{ Methanolic } & \multirow{2}{*}{ S. alba } & 0.5 & $15.55 \pm 0.75$ \\
\hline & & 1 & $13.52 \pm 0.55$ \\
\hline \multirow{2}{*}{ Aqueous } & \multirow{2}{*}{ S. panduriforme } & 0.125 & $11.60 \pm 0.42$ \\
\hline & & 0.5 & $11.84 \pm 0.36$ \\
\hline Methanolic & S. panduriforme & 0.5 & $11.25 \pm 0.21$ \\
\hline \multicolumn{2}{|c|}{ Control } & & \\
\hline \multicolumn{2}{|r|}{ PBS } & $\mathrm{N} / \mathrm{A}$ & $12.92 \pm 0.62$ \\
\hline \multicolumn{2}{|c|}{ Salicylic acid } & 1 & $11.36 \pm 0.54$ \\
\hline
\end{tabular}


Table 3. Extracts that had a significant effect on aPTT $(p<0.05)$

\begin{tabular}{|c|c|c|c|c|c|c|c|}
\hline Plant & $\begin{array}{l}\text { Concentration } \\
(\mathrm{mg} / \mathrm{ml})\end{array}$ & $\begin{array}{l}\text { Aqueous extract } \\
\text { aPTT (s) }\end{array}$ & $\begin{array}{c}\text { Methanolic extract } \\
\text { aPTT (s) }\end{array}$ & Plant & $\begin{array}{l}\text { Concentration } \\
(\mathrm{mg} / \mathrm{ml})\end{array}$ & $\begin{array}{l}\text { Aqueous extract } \\
\text { aPTT (s) }\end{array}$ & $\begin{array}{c}\text { Methanolic extract } \\
\text { aPTT (s) }\end{array}$ \\
\hline \multirow{4}{*}{ C. petersiana } & 0.125 & $59.67 \pm 4.05$ & $88.20 \pm 9.03$ & \multirow{4}{*}{ M. sericea } & 0.125 & $52.33 \pm 3.54$ & $52.83 \pm 3.71$ \\
\hline & 0.25 & $65.33 \pm 6.77$ & $196.50 \pm 1.70$ & & 0.25 & $53.40 \pm 1.60$ & $52.87 \pm 5.18$ \\
\hline & 0.5 & $74.70 \pm 4.56$ & no clot & & 0.5 & $54.50 \pm 3.69$ & $52.20 \pm 2.63$ \\
\hline & 1 & $89.53 \pm 10.59$ & $172.40 \pm 0.00$ & & 1 & $58.77 \pm 4.44$ & $52.40 \pm 3.52$ \\
\hline \multirow{4}{*}{$\begin{array}{c}\text { C. } \\
\text { transvaalensis }\end{array}$} & 0.125 & $59.53 \pm 2.80$ & $59.03 \pm 3.81$ & \multirow{4}{*}{ P. curatellifolia } & 0.125 & $65.97 \pm 7.98$ & $62.90 \pm 5.37$ \\
\hline & 0.25 & $62.33 \pm 5.29$ & $67.90 \pm 3.81$ & & 0.25 & $71.73 \pm 5.60$ & $72.90 \pm 8.14$ \\
\hline & 0.5 & $68.33 \pm 4.86$ & $87.73 \pm 10.82$ & & 0.5 & $84.93 \pm 12.66$ & $116.90 \pm 16.71$ \\
\hline & 1 & $137.40 \pm 22.53$ & - & & 1 & $113.50 \pm 17.18$ & $165.20 \pm 22.69$ \\
\hline \multirow{4}{*}{ D. cinerea } & 0.125 & $54.73 \pm 4.21$ & $54.57 \pm 4.74$ & \multirow{4}{*}{ S. aculeastrum } & 0.125 & $52.90 \pm 4.20$ & $52.60 \pm 4.16$ \\
\hline & 0.25 & $56.10 \pm 3.59$ & $56.13 \pm 2.25$ & & 0.25 & $52.23 \pm 3.81$ & $53.00 \pm 3.54$ \\
\hline & 0.5 & $55.87 \pm 3.72$ & $56.87 \pm 3.86$ & & 0.5 & $53.10 \pm 3.87$ & $53.97 \pm 4.26$ \\
\hline & 1 & $58.13 \pm 1.82$ & $63.87 \pm 4.11$ & & 1 & $56.27 \pm 4.51$ & $54.30 \pm 2.69$ \\
\hline \multirow{3}{*}{ D. melanoxylon } & 0.125 & $78.70 \pm 8.00$ & $57.37 \pm 6.53$ & \multirow{3}{*}{ S. alba } & 0.125 & $59.37 \pm 4.80$ & $59.20 \pm 3.25$ \\
\hline & 0.25 & $101.50 \pm 11.01$ & $55.77 \pm 3.76$ & & 0.25 & $63.63 \pm 4.29$ & $72.23 \pm 5.54$ \\
\hline & 1 & no clot & $56.27 \pm 4.55$ & & 1 & $89.73 \pm 21.14$ & $183.10 \pm 22.36$ \\
\hline \multirow{4}{*}{ H. procumbens } & 0.125 & $53.43 \pm 2.73$ & $54.53 \pm 2.71$ & \multirow{4}{*}{$\begin{array}{c}\text { S. } \\
\text { panduriforme }\end{array}$} & 0.125 & $51.53 \pm 2.63$ & $51.23 \pm 2.68$ \\
\hline & 0.25 & $54.00 \pm 3.10$ & $54.73 \pm 3.60$ & & 0.25 & $51.63 \pm 1.94$ & $52.43 \pm 1.46$ \\
\hline & 0.5 & $52.23 \pm 1.61$ & $55.33 \pm 3.72$ & & 0.5 & $55.43 \pm 3.40$ & $53.00 \pm 1.97$ \\
\hline & 1 & $52.00 \pm 2.66$ & $55.47 \pm 3.95$ & & 1 & $59.17 \pm 3.00$ & $52.73 \pm 3.50$ \\
\hline \multirow{4}{*}{ K. africana } & 0.125 & $56.90 \pm 5.80$ & $56.03 \pm 2.75$ & Control & & & \\
\hline & 0.25 & $55.53 \pm 4.47$ & $56.03 \pm 4.30$ & PBS & N/A & $26.5 \pm 5.69$ & - \\
\hline & 0.5 & $58.13 \pm 3.75$ & $57.07 \pm 3.65$ & \multirow{4}{*}{ Salicylic acid } & 0.125 & $53.07 \pm 2.22$ & - \\
\hline & 1 & $60.90 \pm 3.89$ & $56.97 \pm 3.57$ & & 0.25 & $51.50 \pm 3.75$ & - \\
\hline \multirow{4}{*}{ M. sativa } & 0.125 & $50.20 \pm 2.92$ & $50.70 \pm 2.75$ & & 0.5 & $52.53 \pm 2.40$ & - \\
\hline & 0.25 & $50.33 \pm 3.31$ & $52.50 \pm 2.85$ & & 1 & $58.10 \pm 3.76$ & - \\
\hline & 0.5 & $49.90 \pm 1.95$ & $49.63 \pm 3.45$ & & & & \\
\hline & 1 & $50.40 \pm 2.74$ & $51.20 \pm 1.55$ & & & & \\
\hline
\end{tabular}


Figure 1. Effect of methanolic extracts of Cassia petersiana on prothrombin time $(p<0.05)$

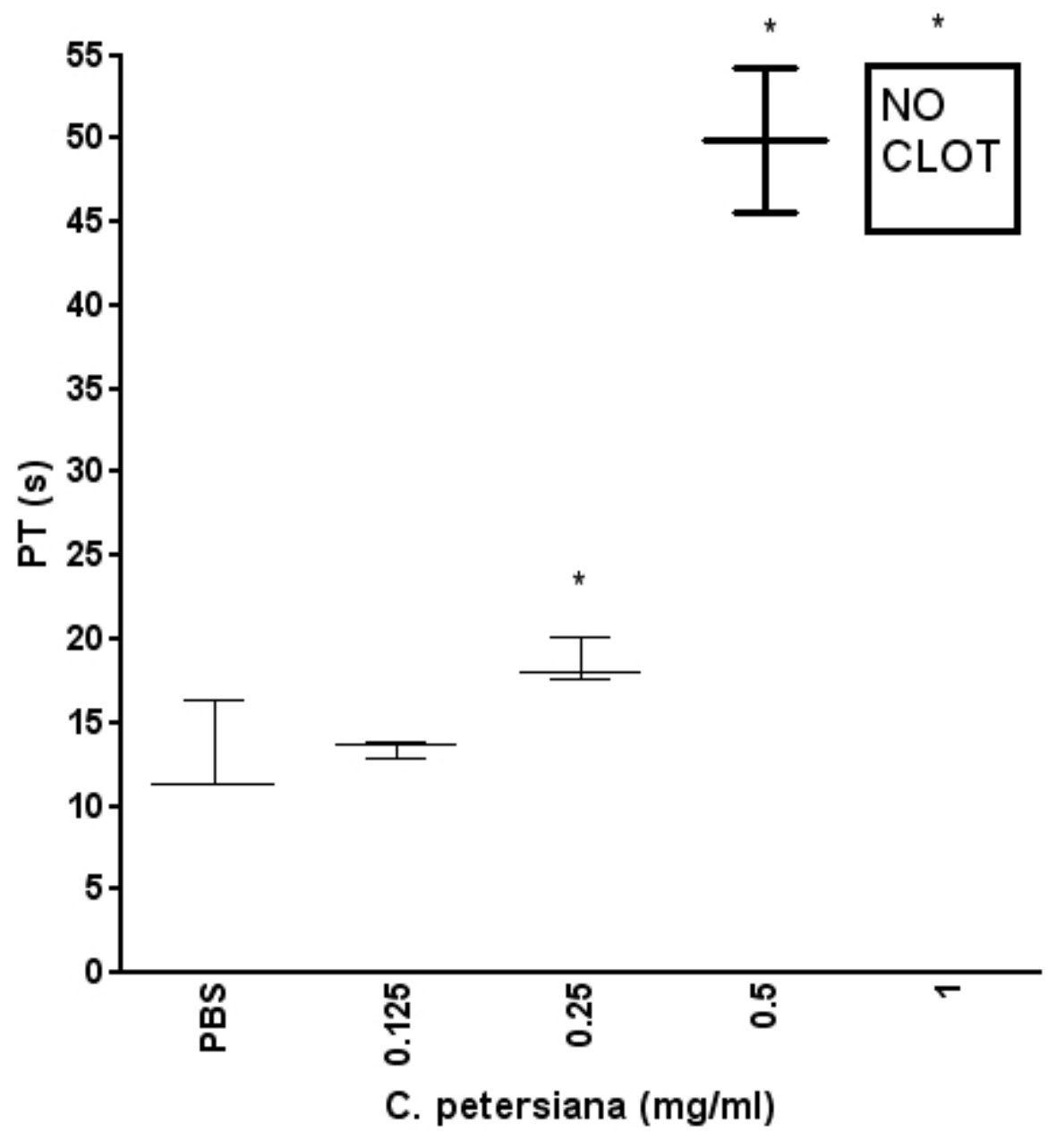


Figure 2. Detection of coumarins by thin-layer chromatography. C18 plate,mobile phase diethyl ether: toluene (1:1 v/v) saturated with $10 \%$ acetic acid. Lane 1: Aqueous extract of Medicago sativa, lane 2: Methanolic extract of Medicago sativa,lane 3:Warfarin.

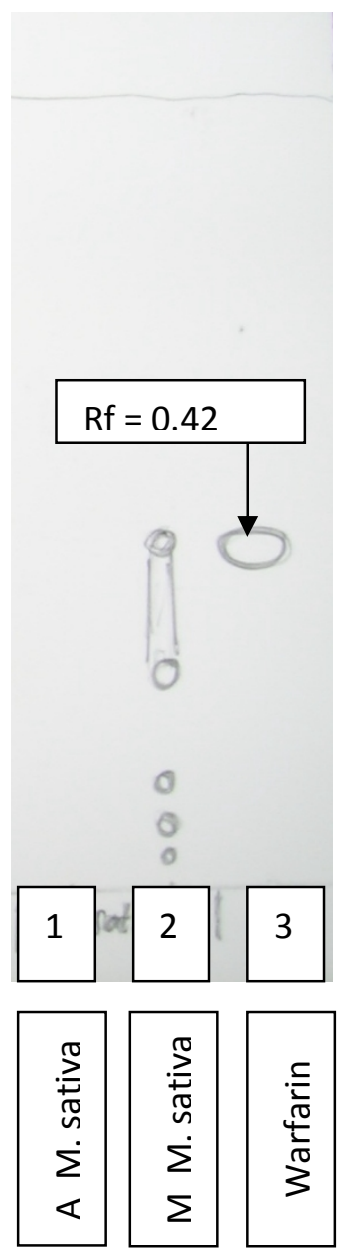


Figure 3. Detection of salicylates by thin-layer chromatography. C18 plate, mobile phase hexane:ethyl acetate:glacial acetic acid (65:35:5 v/v). Lane 1: Salicylic acid, lane 2:

acetylsalicylic acid, lane 3: aqueous extract of Solanum panduriforme, lane 4: methanolic extract of Solanum

panduriforme.

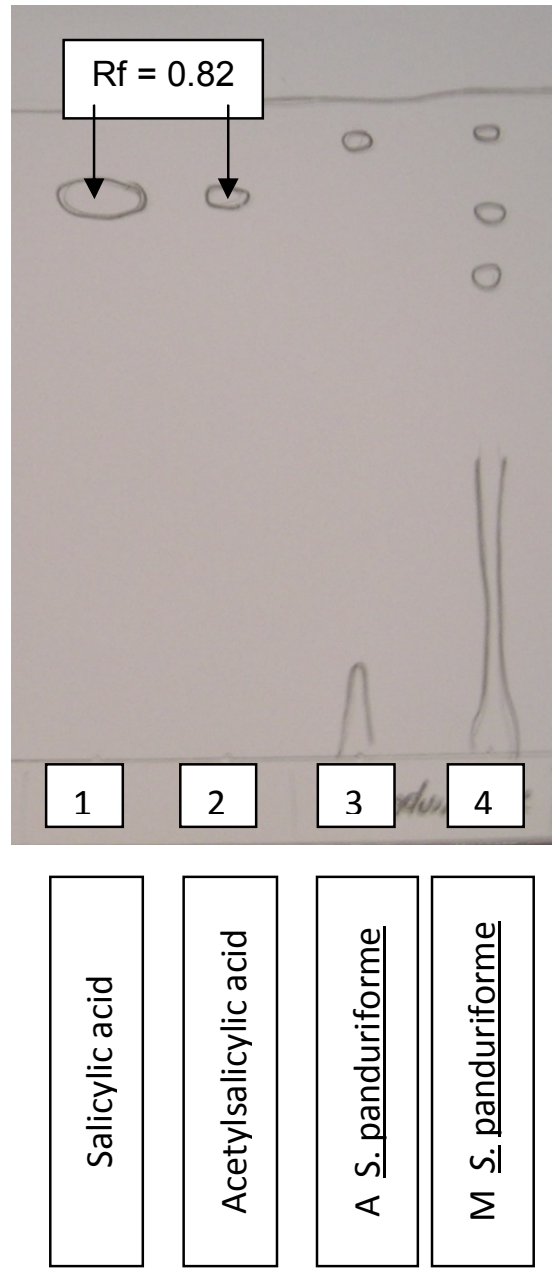

